\title{
Priming-Mediated Systemic Resistance in Cucumber Induced by Pseudomonas azotoformans GC-B19 and Paenibacillus elgii MM-B22 Against Colletotrichum orbiculare
}

\author{
Mee Kyung Sang, Eui Nam Kim, Gyung Deok Han, Min Sun Kwack, Yong Chull Jeun, and Ki Deok Kim
}

First author: Laboratory of Plant Disease and Biocontrol, Division of Biotechnology, Institute of Life Science and Natural Resources, Korea University, Seoul 136-713, Republic of Korea; second, third, fourth, and sixth authors: Laboratory of Plant Disease and Biocontrol, Division of Biotechnology, Korea University, Seoul 136-713, Republic of Korea; and fifth author: Faculty of Bioscience and Industry, College of Applied Life Science, Research Institute for Subtropical Agriculture and Biotechnology, Cheju National University, Jeju 690-756, Republic of Korea.

Accepted for publication 29 January 2014.

\begin{abstract}
Sang, M. K., Kim, E. N., Han, G. D., Kwack, M. S., Jeun, Y. C., and Kim, K. D. 2014. Priming-mediated systemic resistance in cucumber induced by Pseudomonas azotoformans GC-B19 and Paenibacillus elgii MM-B22 against Colletotrichum orbiculare. Phytopathology 104:834-842.

Induced systemic resistance (ISR) can be activated by biotic agents, including root-associated beneficial bacteria to inhibit pathogen infection. We investigated priming-mediated ISR in cucumber induced by Pseudomonas azotoformans GC-B19 and Paenibacillus elgii MM-B22 against Colletotrichum orbiculare (causal fungus of anthracnose). In addition, we examined whether this ISR expression was bacterial density-dependent by assessing peroxidase activity in the presence and absence of the pathogen. As a result, root treatment with the ISR-eliciting strains GC-

tive control), and $\mathrm{MgSO}_{4}$ solution (untreated control). These treatments effectively induced rapid elicitation of hypersensitive reaction-like cell death with $\mathrm{H}_{2} \mathrm{O}_{2}$ generations, and accumulation of defense-related enzymes ( $\beta$-1,3-glucanase, chitinase, and peroxidase) in cucumber leaves in the "primed" state against $C$. orbiculare. In addition, ISR expression was dependent on the bacterial cell density in the rhizosphere. This ISR expression was derived from the presence of sustained bacterial populations ranging from $10^{4}$ to $10^{6}$ cells $/ \mathrm{g}$ of potting mix over a period of time after introduction of bacteria $\left(10^{6}\right.$ to $10^{10} \mathrm{cells} / \mathrm{g}$ of potting mix) into the rhizosphere. Taken together, these results suggest that priming-mediated ISR against $C$. orbiculare in cucumber can be induced in a bacterial density-dependent manner by Pseudomonas azotoformans GC-B19 and Paenibacillus elgii MM-B22.
\end{abstract} B19 and MM-B22 or the chemical inducer DL- $\beta$-amino- $n$-butyric acid (positive control) significantly inhibited fungal infection process (conidial germination and appressorium formation) and disease severity compared with the non-ISR-eliciting strain, Pseudomonas aeruginosa PK-B09 (nega-
Additional keywords: hydrogen peroxide, plant activator, reactive oxygen species.
Plants possess various inducible defense mechanisms to protect themselves against pathogens. Biologically induced disease resistance, referred to as systemic acquired resistance (SAR) or induced systemic resistance (ISR), is generally developed through biochemical and physiological responses and structural changes in host cells. Host responses often involve the rapid production of defense-related enzymes such as peroxidase, $\beta$-1,3-glucanase, and chitinase; expression of pathogenesis-related genes; accumulation of reactive oxygen species (ROS); and histological changes (papillae formation, cell wall lignification, wall apposition, and wall thickening) for induction of a hypersensitive response (HR), resulting in limitation of disease development $(5,35,37,44,53)$.

Induced plant resistance to pathogens can be activated by biotic agents, including plant growth-promoting rhizobacteria (PGPR), or abiotic agents, such as DL- $\beta$-amino- $n$-butyric acid (BABA), benzothiadiazole (BTH), or acibenzolar-S-methyl (ASM) $(14,21$, 26,27,38,46,47,50). Among these agents, certain chemicals, such as BTH (Actigard and Bion), have been used as plant activators to control plant diseases $(29,41)$. However, BTH, having increased defense mechanisms such as production of defense-related pro-

Corresponding author: K. D. Kim; E-mail address: kidkim@korea.ac.kr

*The $\boldsymbol{e}$-Xtra logo stands for "electronic extra" and indicates that the online version contains four supplemental figures.

http://dx.doi.org/10.1094/PHYTO-11-13-0305-R

(c) 2014 The American Phytopathological Society teins, has been shown to retard growth in Arabidopsis thaliana and to cause yield reduction in wheat under pathogen-free field conditions $(8,18)$. It has been, therefore, suggested that these observed trade-offs may result from a balanced allocation of fitness costs between plant growth or development, and the induction of plant defense $(12,17)$.

However, "priming" as a defense response in plants can be also generated immediately following pathogen infection, resulting in efficient use of plant energy for defense $(16,17,44,55)$. A number of abiotic and biotic inducers, such as SAR-mediating chemicals (e.g., salicylic acid, 2,6-dichloroisonicotinic acid, and BTH), ISRmediating rhizobacteria, BABA, mycorrhizal fungi, and others (vitamin $B_{1}$ and volatiles produced by plants or microbes), have been shown to trigger priming-mediated defense $(12,44,46,59)$. Recently, we showed that the priming-mediated defense (ISR) was elicited by chemicals (abiotic factors) from compost water extracts in cucumber and pepper against Colletotrichum orbiculare and $C$. coccodes, respectively (44). This priming-mediated ISR can be also elicited by beneficial microbes (biotic factors), which is shown in this study using the cucumber-C. orbiculare interaction system.

Anthracnose caused by $C$. orbiculare is one of the most important diseases on cucurbits including cucumber; it occurs on leaves, stems, and fruits, and causes deterioration of cucumber fruits $(25,51)$. With efforts to control this important disease, the interaction between cucumber and $C$. orbiculare has been adopted as a model system for ISR with PGPR (56). Thus, we examined 
ISR elicited by two beneficial bacterial strains, which were selected from our previous study (31), using the host-parasite interaction system. The objectives of this study were (i) to examine induction of priming-mediated systemic resistance in cucumber leaves by root-drench treatments with the bacterial strains GC-B19 and MM-B22 against $C$. orbiculare, (ii) to determine defense responses such as inhibition of fungal infection process (conidial germination and appressorium formation), histochemical changes in host cells along with $\mathrm{H}_{2} \mathrm{O}_{2}$ generation, and defense-related enzyme activity, and (iii) to investigate whether this ISR expression might be bacterial density-dependent in the rhizosphere. In addition, we identified strains GC-B19 and MM-B22 using fatty acid-methyl ester (FAME) and 16S rRNA gene sequence analyses.

\section{MATERIALS AND METHODS}

Cucumber plants and growth conditions. Cucumber (Cucumis sativus L. 'Baeknokdadagi') (Syngenta Korea, Seoul, Korea) was used in this study, except in the $\mathrm{H}_{2} \mathrm{O}_{2}$ generation experiment. For the $\mathrm{H}_{2} \mathrm{O}_{2}$ experiment, 'Hangangmatbaekdadagi' (Syngenta Korea) was used because 'Baeknokdadagi' was no longer available. These two cultivars originated from the same maternal line and have very similar characteristics, according to the producer. Cucumber seeds were placed in petri dishes with a layer of moist filter paper (Whatman No. 1) and incubated for $24 \mathrm{~h}$ in the dark at $28^{\circ} \mathrm{C}$. Uniformly germinated seeds were sown into $10-\mathrm{cm}$-diameter plastic pots containing $50 \mathrm{~g}$ of potting mix (peat moss [Acadian Peat Moss Ltd., Lamègue, New Brunswick, Canada] and TKS2 [Floragard Product, Oldenburg, Germany], 1:1.5 [vol/vol]). The pots were placed in a growth room with 16-h fluorescent light per day at room temperature. Cucumber plants were grown for 17 to 20 days (two-leaf stage) or 27 to 30 days (three-leaf stage) until the second or third leaves were expanded to approximately three-quarters of the size of the first or second leaves.

Bacterial strains and control treatments. Based on the results of our previous study (31), the bacterial strains GC-B19 and MMB22 were selected as potential ISR-eliciting strains and Pseudomonas aeruginosa strain PK-B09 (GenBank accession number KC261940) (Supplemental Figure 1) was selected as a non-ISR-eliciting bacterial strain (negative control) against $C$. orbiculare in cucumber plants. These strains were incubated on nutrient agar (NA) (Difco Laboratories, Detroit, MI) for $24 \mathrm{~h}$ at $28^{\circ} \mathrm{C}$. A single colony was selected from each NA plate and grown in $5 \mathrm{ml}$ of nutrient broth (NB) (Difco Laboratories) at $28^{\circ} \mathrm{C}$ in a shaking incubator $(160 \mathrm{rpm})$ for $24 \mathrm{~h}$. The precultured bacteria were transferred to $500 \mathrm{ml}$ of $\mathrm{NB}$ and then incubated with shaking $(160 \mathrm{rpm})$ at $28^{\circ} \mathrm{C}$ for $48 \mathrm{~h}$. The bacterial cells were harvested with $10-\mathrm{mM} \mathrm{MgSO}_{4}$ solution by centrifuging at 5,000 $\times g$ at $20^{\circ} \mathrm{C}$ for $15 \mathrm{~min}$ to remove all culture media. After centrifugation, the supernatants were discarded and pellets (bacterial cells) were washed twice with the same solution followed by centrifugation. Bacterial suspensions were adjusted to $10^{8}$ cells/ $\mathrm{ml}$ (optical density at $600 \mathrm{~nm}=0.5$ ) in the solution. Fifty milliliters of each bacterial suspension ( $1 \mathrm{ml} / \mathrm{g}$ dry weight potting mix) was drenched to the cucumber-growing pots 5 days before inoculation. Fifty milliliters of BABA (100 $\mu \mathrm{g} / \mathrm{ml})$ (Sigma-Aldrich, St. Louis, MO) (44) and $10-\mathrm{mM} \mathrm{MgSO}_{4}$ solution were used as positive and untreated controls, respectively.

Pathogen inoculation and disease assessment. $C$. orbiculare was grown on potato dextrose agar (PDA) (Difco Laboratories) in the dark for 10 days at $28^{\circ} \mathrm{C}$. The fungal conidia were harvested with sterile distilled water amended with $0.03 \%$ Tween 20 ( $\mathrm{vol} / \mathrm{vol})$ and then filtered through four layers of sterile cheese cloth to remove hyphal debris. Conidial suspension was adjusted to $5 \times 10^{5}$ conidia/ml using a haemocytometer. Cucumber plants at the two- or three-leaf stage were inoculated uniformly with the conidial suspension 5 days after treatment with the bacterial strains, BABA, and $10-\mathrm{mM} \mathrm{MgSO}_{4}$ solution. Plants inoculated with Tween 20 alone were used as uninoculated controls. These inoculated plants were placed in a humid chamber with $100 \%$ relative humidity at $28^{\circ} \mathrm{C}$ for $24 \mathrm{~h}$ and then incubated at $25^{\circ} \mathrm{C}$ in a growth room with 16-h fluorescent light per day at room temperature. Disease severity, as expressed by the diseased leaf area $(\%)$, was evaluated on the second or third leaves of cucumber plants at the two- or three-leaf stage 5 days after inoculation (DAI) using the software Matrox Inspector, version 2.2, as described by Kwack et al. (30). In addition, control efficacy (\%) was calculated as follows: (1 - [disease severity on plant leave roottreated with each tested bacterial strain or BABA]/[disease severity on plant leave root-treated with $\mathrm{MgSO}_{4}$ solution]) $\times 100$. To examine induction of ISR by the bacterial strains, the disease severity caused by $C$. orbiculare on third leaves of cucumber plants at the three-leaf stage was assessed twice with 10 replicates each.

Fluorescence microscopy for fungal infection structures. Cucumber plants (three-leaf stage) root-treated with the bacterial strains, BABA, and $\mathrm{MgSO}_{4}$ solution were inoculated with and without $C$. orbiculare for observing fungal infection structures, such as germinated conidia and appressoria, by using the method described by Jeun et al. (20). The third leaves of the inoculated plants were punched using a 1-cm-diameter cork borer (eight discs per leaf). Sampled leaf discs were fixed with $1 \%$ glutaraldehyde in $0.05 \mathrm{M}$ sodium phosphate buffer $(\mathrm{pH} 7.2)$ for $2 \mathrm{~h}$ and washed with sodium phosphate buffer three times for $10 \mathrm{~min}$ each. The fixed leaf discs were stained with $0.02 \%$ Uvitex $2 \mathrm{~B}$ (wt/vol) (diethanol) for $20 \mathrm{~min}$ to observe the fungal structures. After washing with the same buffer three times for $10 \mathrm{~min}$ each, the leaf discs were mounted on glass slides with $80 \%$ glycerol. The infection structures on the inoculated tissues were observed using a fluorescence microscope (Olympus, Tokyo, Japan) equipped with a $U$ set of filters. More than 100 conidia per leaf (replication) were observed to determine rates of conidial germination and appressorium formation. Numbers of total conidia, germinated conidia, and appressoria were counted on the leaf tissues 4 DAI. Percent conidial germination and appressorium formation were calculated as follows: conidial germination $(\%)=$ number of germinated conidia/number of total conidia $\times 100$; appressorium formation $(\%)=$ number of conidia with appressoria/number of germinated conidia $\times 100$. The experiments were conducted twice with three replicates each.

Histological analysis for ROS and cell death. Cucumber plants (three-leaf stage) root-treated with the bacterial strains, $\mathrm{BABA}$, and $\mathrm{MgSO}_{4}$ solution were prepared as described above. The third leaves of the plants were punched using a $1.5-\mathrm{cm}$ diameter cork borer $48 \mathrm{~h}$ after inoculation (HAI) with and without C. orbiculare. Superoxide anion $\left(\mathrm{O}_{2}^{-}\right)$generation was examined by staining sampled leaf discs with $0.1 \%$ nitroblue tetrazolium (NBT) (wt/vol) and $10 \mathrm{mM} \mathrm{NaN}_{3}$ in $10 \mathrm{mM}$ potassium phosphate buffer ( $\mathrm{pH}$ 6.4). The infiltrated leaf discs were placed under light for $30 \mathrm{~min}$ and then immersed in a mixture of lactic acid, phenol, and water $(1: 1: 1, \mathrm{vol} / \mathrm{vol} / \mathrm{vol})$ for 2 days in the dark at room temperature. Infiltrated leaf discs were then destained in ethanol/ chloroform $(4: 1, \mathrm{vol} / \mathrm{vol})$ containing $0.15 \%$ trichloroacetic acid (TCA) (wt/vol) (9). Likewise, histochemical detection of hydrogen peroxide $\left(\mathrm{H}_{2} \mathrm{O}_{2}\right)$ was performed by infiltrating $0.1 \%(\mathrm{wt} / \mathrm{vol})$ 3,3'-diaminobenzide (DAB)-HCl solution ( $\mathrm{pH}$ 3.8) (SigmaAldrich) for 12 to $15 \mathrm{~h}$ in the dark. The infiltrated leaf discs were destained in ethanol for $24 \mathrm{~h}$ at room temperature (53). Histochemical detection of cell death was conducted by Evans Blue staining (48); leaf discs were immersed in $0.25 \%$ Evans Blue (wt/vol) for $1 \mathrm{~h}$ in a shaker $(100 \mathrm{rpm})$ and excess dye was removed with water. The leaf discs were observed using a microscope and the experiments were conducted twice with three replicates each. 
$\mathrm{H}_{2} \mathrm{O}_{2}$ generation in cucumber leaves induced by bacterial strains. Cucumber plant (three-leaf stage) preparation and treatments, as well as pathogen inoculation and disease assessment, were conducted as described above. Third leaves of the plants were punched using a 0.5 -cm-diameter cork borer $(15$ discs per leaf) $0,6,12,24$, and $48 \mathrm{HAI}$ with or without $C$. orbiculare. The sampled leaf discs were soaked in $1 \mathrm{ml}$ of assay mixture containing $250 \mu \mathrm{M}$ ferrous ammonium sulfate and $100 \mu \mathrm{M}$ sorbitol in $25 \mathrm{mM} \mathrm{H}_{2} \mathrm{SO}_{4}$. After centrifugation at 5,000 $\times g$ at $4{ }^{\circ} \mathrm{C}$ for $10 \mathrm{~min}$, the supernatant $(500 \mu \mathrm{l})$ was added to $100 \mu \mathrm{M}$ xylenol orange reagent $(500 \mu \mathrm{l})$ and incubated for $30 \mathrm{~min}$. $\mathrm{H}_{2} \mathrm{O}_{2}$ production, expressed as $\mu \mathrm{mol} / \mathrm{cm}^{2}$ leaf area, was determined by measuring the absorbance at $560 \mathrm{~nm}$ using a microplate spectrophotometer (Powerwave XS, Bio-Tek, Winooski, VT), as described by Gay et al. (11). A standard curve for $\mathrm{H}_{2} \mathrm{O}_{2}$ (Sigma-Aldrich) was used for calculating $\mathrm{H}_{2} \mathrm{O}_{2}$ generation in the leaf tissues. The assays were conducted twice with three and four replicates.

$\boldsymbol{\beta}-1,3-G l u c a n a s e$, chitinase, and peroxidase activities. $\beta-1,3$ Glucanase, chitinase, and peroxidase activities in the third leaves of cucumber plants (three-leaf stage), prepared as described above, were assessed $1,3,5$, and 7 DAI with or without $C$. orbiculare. $\beta-1,3$-Glucanase activity was measured as the rate of reducing-sugar production with laminarin (Sigma-Aldrich) as a substrate, as described by Kauffmann et al. (22); the activity was expressed as $\mu \mathrm{mol}$ of glucose equivalent $/ \mathrm{min} / \mathrm{mg}$ of protein. Chitinase activity was measured using a colorimetric assay for $\mathrm{N}$ acetylglucosamine (GlcNAc) as described by Abeles et al. (1); the activity was expressed as nmol of GlcNAc equivalent $/ \mathrm{min} / \mathrm{mg}$ of protein. Peroxidase activity was determined using guaiacol as the hydrogen donor, according to the method described by Hammerschmidt et al. (15); the activity was expressed as the change in absorbance at $470 \mathrm{~nm} / \mathrm{min} / \mathrm{mg}$ protein. These protein assays were conducted with bovine serum albumin as a standard, according to the procedure described by Bradford (4). These enzyme assays were conducted twice with four replicates each.

Bacterial cell density in cucumber rhizosphere. The effect of bacterial cell density in rhizosphere on peroxidase activity and disease severity was evaluated in the cucumber plants (two-leaf stage) 3 and 5 DAI, respectively, prepared as described above. Plants were root-treated with various cell suspensions $\left(0,10^{2}, 10^{4}\right.$,

TABLE 1. Disease severity, conidial germination, and appressorium formation of Colletotrichum orbiculare on the third leaves of cucumber ('Baeknokdadagi') plants at the three-leaf stage, in which the plants were root-drenched with the induced systemic resistance (ISR)-eliciting bacterial strains GC-B19 and MM-B22 5 days before inoculation

\begin{tabular}{lccc}
\hline Treatment & $\begin{array}{c}\text { Disease } \\
\text { severity }(\%)^{\mathrm{x}}\end{array}$ & $\begin{array}{c}\text { Conidial } \\
\text { germination }(\%)^{\mathrm{y}}\end{array}$ & $\begin{array}{c}\text { Appressorium } \\
\text { formation }(\%)\end{array}$ \\
\hline $\mathrm{MgSO}_{4}$ & $5.4 \pm 0.6 \mathrm{a}^{\mathrm{z}}$ & $52.1 \pm 1.7 \mathrm{a}$ & $48.0 \pm 1.2 \mathrm{a}$ \\
$\mathrm{BABA}$ & $1.1 \pm 0.1 \mathrm{c}$ & $44.1 \pm 1.9 \mathrm{~b}$ & $36.1 \pm 3.9 \mathrm{~b}$ \\
$\mathrm{GC}-\mathrm{B} 19$ & $1.8 \pm 0.2 \mathrm{bc}$ & $35.2 \pm 2.6 \mathrm{c}$ & $34.0 \pm 3.1 \mathrm{~b}$ \\
MM-B22 & $2.4 \pm 0.4 \mathrm{~b}$ & $39.7 \pm 1.9 \mathrm{bc}$ & $35.3 \pm 0.8 \mathrm{~b}$ \\
PK-B09 & $4.4 \pm 0.5 \mathrm{a}$ & $53.8 \pm 1.6 \mathrm{a}$ & $48.4 \pm 3.1 \mathrm{a}$ \\
\hline
\end{tabular}

${ }^{\mathrm{x}}$ Disease severity $(\%)$ was determined 5 days after inoculation (DAI) with C. orbiculare $\left(5 \times 10^{5}\right.$ conidia/ml $)$ on the third leaves of cucumber plants treated with bacterial suspensions $\left(10^{8}\right.$ cells $\left./ \mathrm{ml}\right)$ of the ISR-eliciting strains and Pseudomonas aeruginosa PK-B09 (negative bacterial control), DL- $\beta$ amino- $n$-butyric acid (BABA; $100 \mu \mathrm{g} / \mathrm{ml}$ ) (positive chemical control), and 10-mM $\mathrm{MgSO}_{4}$ solution (untreated control). Uninoculated plants did not exhibit any disease symptoms.

y Approximately 100 conidia per leaf (replication) were observed at $4 \mathrm{DAI}$; conidial germination (\%) among the observed conidia and appressorium formation (\%) among the germinated conidia were determined.

${ }^{\mathrm{z}}$ Means \pm standard errors followed by the same letters are not significantly different according to the least significant difference test at $P<0.05$. Arcsine square root-transformed data for percent disease severity, conidial germination, and appressorium formation were used for the statistical analysis; however, untransformed data are presented. The experiments were conducted twice with 10 replicates each for disease severity and three replicates each for conidial germination and appressorium formation.
$10^{6}, 10^{8}$, and $10^{10}$ cells $/ \mathrm{ml}$ ) of the bacterial strains, BABA, and $\mathrm{MgSO}_{4}$ solution, as described above. The cell suspensions were obtained by serial dilution of $10^{8}$ cells $/ \mathrm{ml}$ or by condensing to $10^{10}$ cells $/ \mathrm{ml}$. The experiments were conducted twice with three replicates each for peroxidase activity and six replicates each for disease severity.

To assess bacterial population changes in the cucumber rhizosphere over a period of time, spontaneous rifampicin-resistant mutants (GC-B19Rif, MM-B22Rif, and PK-B09Rif) of strains GC-B19, MM-B22, and PK-B09 were prepared as described by Kim et al. (24). The growth, colony morphology, and disease inhibition ability of the mutants were compared with the wild types. Various cell suspensions $\left(0,10^{2}, 10^{4}, 10^{6}, 10^{8}\right.$, and $10^{10}$ cells $/ \mathrm{ml}$ ) of the rifampicin-resistant mutants were root-treated to the plants (two-leaf stage), as described above. Cucumber rhizosphere soils ( $3 \mathrm{~g})$ were collected at $0(3 \mathrm{~h}), 4,8$, and 12 days after bacterial treatment, and these soils were suspended with $10-\mathrm{mM}$ $\mathrm{MgSO}_{4}$ solution for $30 \mathrm{~min}$ in a shaking incubator $(160 \mathrm{rpm})$ at $28^{\circ} \mathrm{C}$. The soil suspensions were spread and incubated on tryptic soy agar containing rifampicin $(100 \mu \mathrm{g} / \mathrm{ml})$ at $28^{\circ} \mathrm{C}$ for $48 \mathrm{~h}$. Bacterial colonies appeared on the medium were counted and the populations were expressed as colony forming units (CFU) per gram of dry weight potting mix. The experiments were conducted twice with three replicates each.

Identification of bacterial strains by FAME and 16S rRNA gene sequence analyses. Cellular FAME analysis of strains GCB19 and MM-B22 was analyzed by gas chromatography using the Microbial Identification System (MIDI; Newark, DE) according to the manufacturer's instruction. For 16S rRNA gene sequence analysis, total genomic DNA of strains GC-B19 and MM-B22 was isolated using a QIAGEN Genomic-tip kit (Qiagen GmbhH, Hilden, Germany) according to the manufacturer's instructions. The 16S rRNA genes of the strains were amplified by polymerase chain reaction (PCR) using the universal primers fD1 (forward) 5'-AGAGTTTGATCCTGGCTCAG-3' and rP2 (reverse) 5'-ACG GCTACCTTGTTACGACTT-3' (57). The PCR was performed as follows: 35 cycles of $95^{\circ} \mathrm{C}$ for $4 \mathrm{~min}, 58^{\circ} \mathrm{C}$ for $1 \mathrm{~min}$, and $72^{\circ} \mathrm{C}$ for $2 \mathrm{~min}$, followed by $72^{\circ} \mathrm{C}$ for $8 \mathrm{~min}$ as a final extension step. PCR products were purified using a gel extraction kit (iNtRON Biotechnology, Seongnam, Korea), and the purified PCR products were sequenced by the Cosmogenetech Sequencing Service (Cosmogenetech, Seoul, Korea). The DNA sequences were analyzed using BLAST (http://blast.ncbi.nlm.nih.gov/ Blast.cgi), and sequences of related strains belonging to each genus were obtained from the National Center for Biotechnology Information (NCBI) GenBank database. After performing multiple sequence alignments with the CLUSTAL W program (52), phylogenetic analyses were conducted with the neighbor-joining method using the Molecular Evolutionary Genetics Analysis (MEGA) version 5.1 software package $(28,43)$. Bootstrap analysis with 1,000 replicates was used to evaluate the stability of the groups in the neighbor-joining tree (10). The 16S rRNA sequences of strains GC-B19 (accession number KC261941) and MM-B22 (KC261939) have been deposited in GenBank.

Statistical analysis of data. Statistical analysis of data was conducted using the Statistical Analysis System Software (SAS Institute, Cary, NC). Pooled data from repeated experiments were used for statistical analysis after confirming the homogeneity of the variances using the Levene's test (32). Percentage data for disease severity, conidial germination, and appressorium formation were statistically analyzed after arcsine-root transformation, whereas data for bacterial population were analyzed after log transformation. For data related to peroxidase activity affected by bacterial cell density, contrast analysis was conducted to compare the means between inoculated and uninoculated plants. Analysis of variance was performed using the general linear model procedure and means were separated by the least significant difference test at $P<0.05$. 


\section{RESULTS}

Effect of bacterial strains on ISR against $C$. orbiculare in cucumber leaves. Root treatment with strains GC-B19 and MMB22 significantly $(P<0.05)$ reduced the severity of anthracnose caused by $C$. orbiculare in 66.7 and $55.6 \%$, respectively, of third leaves of cucumber plants compared with $\mathrm{MgSO}_{4}$ solution (untreated control) (Fig. 1, Table 1). Similarly, treatment with BABA (positive chemical control) significantly $(P<0.05)$ reduced disease severity in $79.6 \%$ of plants; however, treatment with strain PK-B09 (negative bacterial control) failed to significantly $(P>$ 0.05 ) reduce disease severity (Fig. 1, Table 1).
Observation of $C$. orbiculare infection structures on cucumber leaves using fluorescence microscopy (Supplemental Figure 2) showed that treatment with strains GC-B19 and MM-B22 and BABA significantly $(P<0.05)$ inhibited both conidial germination and appressorium formation compared with $\mathrm{MgSO}_{4}$ solution. However, treatment with strain PK-B09 failed to reduce conidial germination and appressorium formation (Table 1).

Effect of ISR-eliciting strains on ROS generation and cell death. In histological analyses, NBT and DAB staining of third leaves of cucumber plants showed accumulations of $\operatorname{ROS}\left(\mathrm{O}_{2}^{-}\right.$ [Fig. 2A] and $\mathrm{H}_{2} \mathrm{O}_{2}$ [Fig. 2B]) 48 HAI with C. orbiculare (Fig. 2 [+]) compared with uninoculated leaves (Fig. $2[-])$. Higher levels
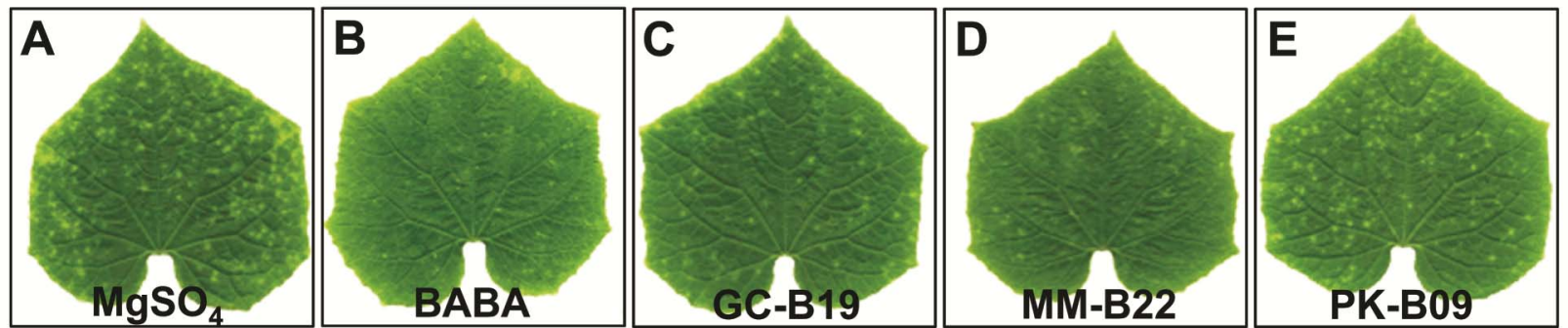

Fig. 1. Photographs of diseased third leaves caused by Colletotrichum orbiculare $\left(5 \times 10^{5}\right.$ conidia/ml $)$ on cucumber plants at the three-leaf-stage ('Baeknokdadagi') 5 days after inoculation, in which the plants were root-drenched with $\mathbf{A}, 10 \mathrm{mM} \mathrm{MgSO}_{4}$ solution (untreated control), B, DL- $\beta$-amino- $n$-butyric acid (BABA; $100 \mu \mathrm{g} / \mathrm{ml}$ ) (positive chemical control), and bacterial suspensions $\left(10^{8} \mathrm{cells} / \mathrm{ml}\right)$ of the induced systemic resistance-eliciting strains (C, GC-B19 and D, MM-B22) and E, Pseudomonas aeruginosa PK-B09 (negative bacterial control) 5 days before inoculation. The experiments were conducted twice with 10 replicates each.

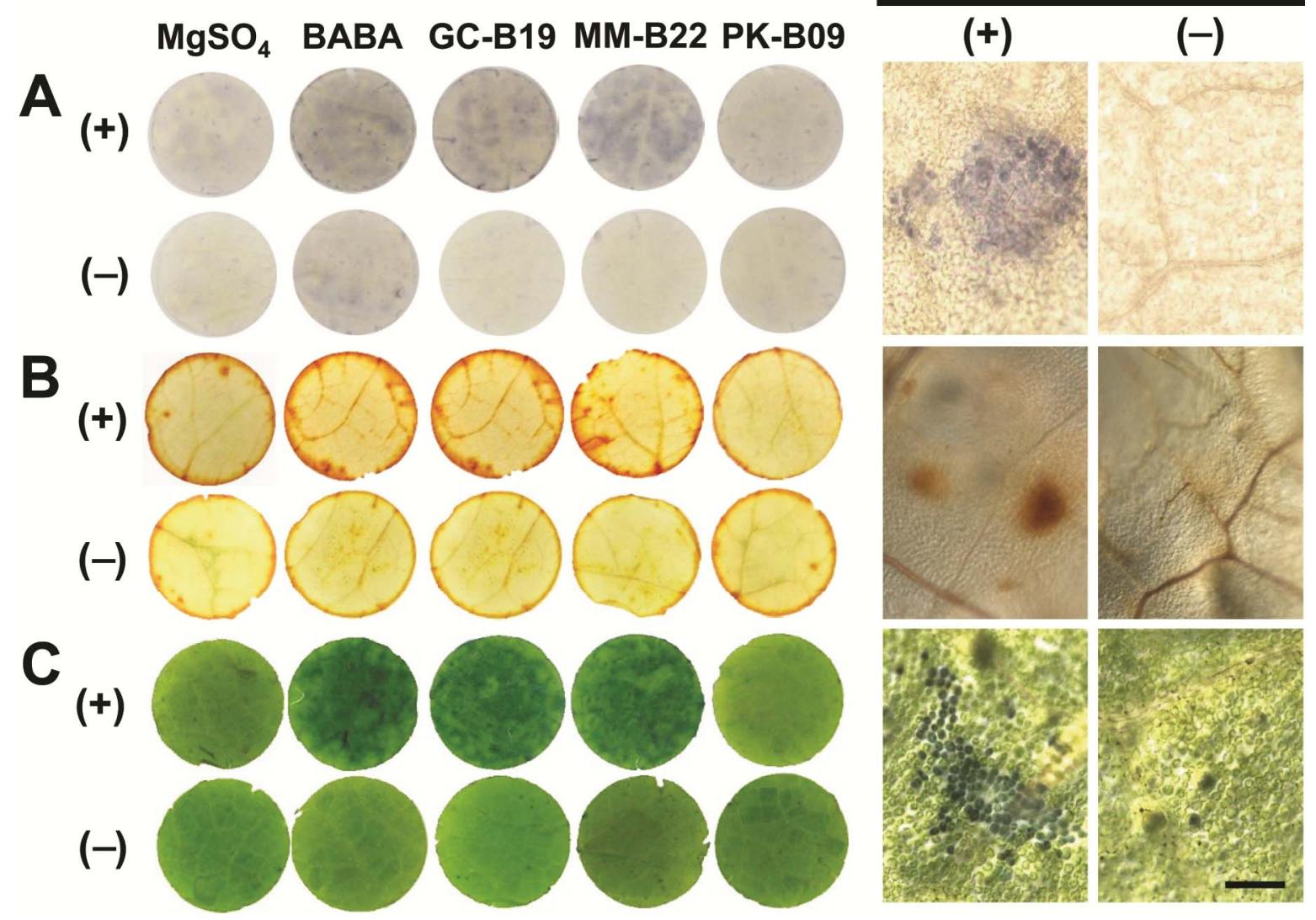

Fig. 2. Histochemical detection of reactive oxygen species $\left(\mathrm{O}_{2}{ }^{-}\right.$and $\left.\mathrm{H}_{2} \mathrm{O}_{2}\right)$ and cell death in the third leaves of cucumber ('Baeknokdadagi') plants at the three-leaf stage inoculated with and without Colletotrichum orbiculare $\left(5 \times 10^{5}\right.$ conidia/ml). A, $\mathrm{O}_{2}^{-}$and $\mathbf{B}, \mathrm{H}_{2} \mathrm{O}_{2}$ were stained by using nitroblue tetrazolium and 3,3'diaminobenzidine staining, respectively, and $\mathbf{C}$, cell death was detected by Evans-Blue staining in the leaves $48 \mathrm{~h}$ after inoculation. The plants were root-drenched with bacterial suspensions $\left(10^{8} \mathrm{cells} / \mathrm{ml}\right)$ of the induced systemic resistance-eliciting strains (GC-B19 and MM-B22) and Pseudomonas aeruginosa PK-B09 (negative bacterial control), DL- $\beta$-amino- $n$-butyric acid (BABA; $100 \mu \mathrm{g} / \mathrm{ml}$ ) (positive chemical control), and $10-\mathrm{mM} \mathrm{MgSO}_{4}$ solution (untreated control) 5 days before inoculation. Disease severity of the inoculated leaves is shown in Table 1 . Scale bar, $10 \mu \mathrm{m} ;+$, inoculated; -, uninoculated. The experiments were conducted twice with three replicates each. 
of ROS were detected in leaves of the plants root-treated with the ISR-eliciting strains GC-B19 and MM-B22 and the chemical inducer BABA (positive control) compared with leaves treated with $\mathrm{MgSO}_{4}$ solution (untreated control). However, treatment with the non-ISR-eliciting strain PK-B09 (negative bacterial control) also produced similar levels of $\mathrm{O}_{2}^{-}$and $\mathrm{H}_{2} \mathrm{O}_{2}$ in the leaves compared with $\mathrm{MgSO}_{4}$ solution (Fig. 2A and B). In addition,

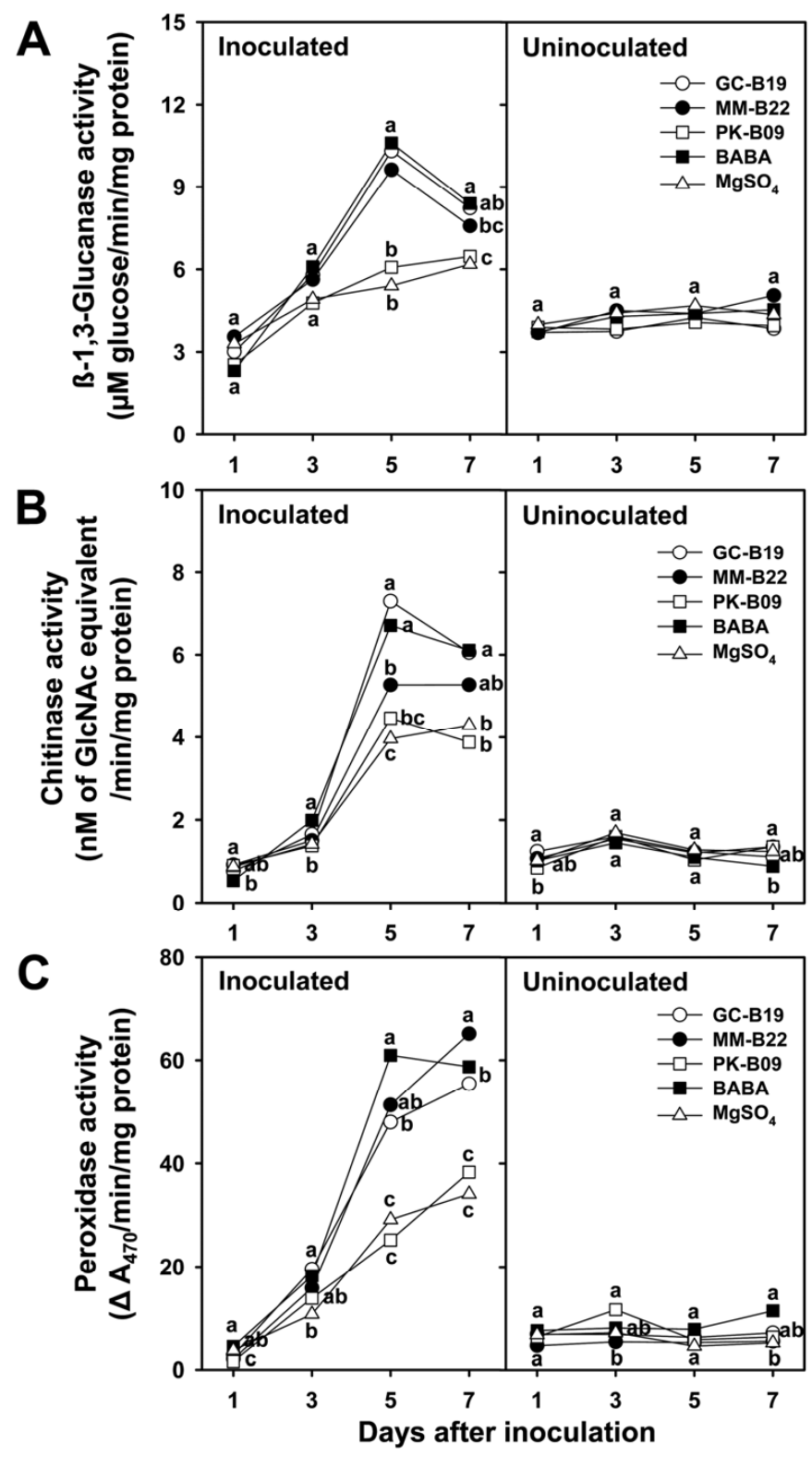

Fig. 3. A, $\beta-1,3-$ Glucanase, $\mathbf{B}$, chitinase, and $\mathbf{C}$, peroxidase activities in the third leaves of cucumber ('Baeknokdadagi') plants at the three-leaf stage inoculated with and without Colletotrichum orbiculare $\left(5 \times 10^{5}\right.$ conidia/ml $)$. The plants were root-drenched with bacterial suspensions $\left(10^{8}\right.$ cells $\left./ \mathrm{ml}\right)$ of the induced systemic resistance-eliciting strains (GC-B19 [GC] and MM-B22 [MM]) and Pseudomonas aeruginosa PK-B09 (PK) (negative bacterial control), DL- $\beta$-amino- $n$-butyric acid (BABA; $100 \mu \mathrm{g} / \mathrm{ml}$ ) (positive chemical control), and $10-\mathrm{mM} \mathrm{MgSO}_{4}$ solution (untreated control) 5 days before inoculation. $\beta$ $1,3-$ Glucanase activity was expressed as $\mu \mathrm{mol}$ of glucose equivalent $/ \mathrm{min} / \mathrm{mg}$ of protein; chitinase activity as nmol of $N$-acetylglucosamine (GlcNAc) equivalent $/ \mathrm{min} / \mathrm{mg}$ of protein; peroxidase activity as the change in absorbance at $470 \mathrm{~nm} / \mathrm{min} / \mathrm{mg}$ of protein. Means indicated by different letters are significantly different according to the least significant difference test at $P<0.05$. The experiments were conducted twice with four replicates each. Disease severity (mean \pm standard error, $n=20$ ) of the inoculated leaves was as follows: GC-B19 $=1.35 \pm 0.14$, MM-B22 $=1.89 \pm 0.21$, PK-B09 $=4.47 \pm 0.46$, $\mathrm{BABA}=0.84 \pm 0.09$, and $\mathrm{MgSO}_{4}=5.04 \pm 0.39 \%$. Uninoculated $=$ no disease symptoms.
Evans-Blue staining for detecting cell death in the leaves showed blue spots, indicating cell death (Fig. 2C). Treatment with strains GC-B19 and MM-B22 and BABA caused more cell death than treatment with strain $\mathrm{PK}-\mathrm{B} 09$ or $\mathrm{MgSO}_{4}$ solution (Fig. 2C).

Assessment of $\mathrm{H}_{2} \mathrm{O}_{2}$ generation in third leaves of cucumber plants showed that $\mathrm{H}_{2} \mathrm{O}_{2}$ increased greatly in plants treated with strains GC-B19 and MM-B22 and BABA at 0 to $24 \mathrm{HAI} ; \mathrm{H}_{2} \mathrm{O}_{2}$ declined slightly at $48 \mathrm{HAI}$ with $C$. orbiculare (Supplemental Figure 3A). However, treatment with strain PK-B09 or $\mathrm{MgSO}_{4}$ solution produced a slight increase in $\mathrm{H}_{2} \mathrm{O}_{2}$ at 0 to $24 \mathrm{HAI}$, which declined $48 \mathrm{HAI}$. On the contrary, in uninoculated leaves, $\mathrm{H}_{2} \mathrm{O}_{2}$ generation remained low over time in all treatments and did not differ substantially between treatments over time.

Effect of ISR-eliciting strains on defense-related enzyme production. Changes in activities of defense-related enzymes, such as $\beta$-1,3-glucanase (Fig. 3A), chitinase (Fig. 3B), and peroxidase (Fig. 3C), were observed in third leaves of cucumber plants root-treated with all treatments over 7 DAI with $C$. orbiculare (Fig. 3). Activity levels of all enzymes tested increased from 1 to 5 DAI; $\beta$-1,3-glucanase and chitinase activities persisted or declined, whereas peroxidase activity persisted or increased 7 DAI. Treatment with the ISR-eliciting strains GC-B19 and MMB22 and the chemical inducer BABA (positive chemical control) caused higher levels of enzyme activity than the negative control such as strain PK-B09 or $\mathrm{MgSO}_{4}$ solution at 5 and 7 DAI. Strain PK-B09 (negative bacterial control) and $\mathrm{MgSO}_{4}$ solution (untreated control) elicited similar levels of $\beta$-1,3-glucanase, chitinase, and peroxidase activity over 7 DAI. However, in uninoculated cucumber leaves, enzyme activities showed consistently low levels and no great differences between treatments during the period of evaluation (Fig. 3).

Effect of bacterial cell density on ISR against $\boldsymbol{C}$. orbiculare in cucumber leaves. Statistical analysis of all treatments regardless of variation in bacterial cell density indicated that treatment with strains GC-B19 and MM-B22 and BABA (positive chemical control) significantly $(P<0.05)$ reduced disease severity and peroxidase activity in inoculated second leaves of cucumber plants compared with treatment with strain PK-B09 (negative bacterial control) or $\mathrm{MgSO}_{4}$ solution (untreated control) (Table 2). Higher density treatment $\left(10^{6}\right.$ to $10^{10}$ cells/g of potting mix $)$ of strains GC-B19 and MM-B22 significantly $(P<0.05)$ reduced disease severity and peroxidase activity compared with lower density treatment $\left(10^{2}\right.$ to $10^{4}$ cells/g of potting mix). However, the non-ISR-eliciting strain PK-B09 failed to reduce disease severity and to increase peroxidase activity, regardless of cell density, but increased peroxidase activity at the highest cell density (Table 2). However, in uninoculated leaves, no distinct differences in peroxidase activity were detected for the various cell densities tested. In addition, contrast analysis showed that at densities of $10^{6}$ to $10^{10}$ cells/g of potting mix of strains GC-B19 and MM-B22 as well as BABA and $\mathrm{MgSO}_{4}$ solution, peroxidase activity differed significantly $(P<0.05)$ between inoculated and uninoculated leaves. In the case of strain PK-B09, the highest cell density treatment $\left(10^{10}\right.$ cells/g of potting mix) only produced a significant $(P<0.05)$ difference between inoculated and uninoculated leaves (Table 2).

Population change of rifampicin-resistant mutants in cucumber rhizosphere. When spontaneous rifampicin-resistant mutant strains (GC-B19Rif, MM-B22Rif, and PK-B09Rif) were treated at higher cell density $\left(10^{6}\right.$ to $10^{10}$ cells/g of potting mix) into the rhizosphere of cucumber plants, mutant populations significantly decreased $4 \mathrm{DAI}$; however, the populations generally maintained at approximately $10^{5}$ to $10^{6}$ cells/g of potting mix over the 12 days after treatment (Supplemental Figure 4). Likewise, the plant roots treated with lower cell density $\left(10^{2}\right.$ to $10^{4}$ cells/g of potting mix) of the mutants showed that the populations decreased slightly 4 days after treatment and then held steady at levels of $10^{2}$ to $10^{3}$ cells/g of potting mix over the 12 days after treatment. 
Identification of ISR-eliciting bacterial strains by FAME and $16 S$ rRNA gene sequence analyses. The ISR-eliciting strains GC-B19 and MM-B22 were identified as Pseudomonas azotoformans and Paenibacillus elgii, respectively, based on FAME and 16S rRNA sequence analyses. From the FAME profiles, the major cellular fatty acids of strain GC-B19 were summed feature 3 $\left(\mathrm{C}_{16: 1} \omega 6 c / \mathrm{C}_{16: 1} \omega 7 c\right)(37.51 \%), \mathrm{C}_{16: 0}(33.59 \%)$, and summed feature $8\left(\mathrm{C}_{18: 1} \omega 6 c / \mathrm{C}_{18: 1} \omega 7 c\right)(12.27 \%)$, which identified the strain as belonging to the genus Pseudomonas. Strain MM-B22 mainly had $\mathrm{C}_{15: 0}$ anteiso $(54.83 \%)$ and $\mathrm{C}_{16: 0}(11.25 \%)$, and was identified as belonging to the genus Paenibacillus. On the other hand, 16S rRNA sequence analysis showed that strain GC-B19 $(1,410 \mathrm{bp})$ exhibited $99.3,98.9,98.3$, and $98.2 \%$ similarity to Pseudomonas azotoformans KS0034 ${ }^{\mathrm{T}}$ (NR037092), Pseudomonas cedrina DSM 14938 ${ }^{\mathrm{T}}$ (AJ492830), Pseudomonas salomonii CFBP2022 ${ }^{\mathrm{T}}$ (NR029051), and Pseudomonas orientalis CFML96$170^{\mathrm{T}}$ (NR024909), respectively; strain MM-B22 (1,402 bp) showed 99.5, 99.2, and 98.5\% similarity to Paenibacillus elgii NBRC $100335^{\mathrm{T}}$ (AB681151), Paenibacillus ehimensis KCTC $3748^{\mathrm{T}}$ (NR025666), and Paenibacillus koreensis $\mathrm{YC} 300^{\mathrm{T}}$ (NR028747), respectively (Fig. 4).

\section{DISCUSSION}

In our previous study, we showed that priming-mediated ISR was induced in pepper and cucumber against $C$. coccodes and $C$. orbiculare, respectively, by compost water extracts (abiotic factors) (44). In this study, we demonstrated that this ISR could also be triggered by beneficial microbes (biotic factors). The present results revealed that root treatments with Pseudomonas azotoformans strain GC-B19 and Paenibacillus elgii strain MMB22 effectively inhibited fungal infection process (conidial germination and appressorium formation) and the severity of anthracnose caused by $C$. orbiculare in cucumber leaves. In particular, these strains induced rapid elicitation of HR-like cell death with $\mathrm{H}_{2} \mathrm{O}_{2}$ generation and accumulation of defense-related enzymes ( $\beta$-1,3-glucanase, chitinase, and peroxidase) in leaves in the primed (i.e., no defense activation in the absence of a pathogen) state against $C$. orbiculare. In addition, we found that expression of induced resistance was dependent on the bacterial cell density in the rhizosphere of cucumber plants.

Benhamou et al. (3) demonstrated induction of disease resistance by Serratia plymuthica in cucumber, in which Pythium ultimum colonization was restricted by the deposition of enlarged callose-enriched wall appositions at sites of pathogen penetration. Recently, we reported that root treatments with beneficial rhizobacteria reduced the severity of anthracnose caused by the airborne fungus $C$. acutatum on pepper fruits $(46,47)$. This reduction in disease severity may have resulted from indirect effect (i.e., ISR) of bacterial strains or direct effect of a bacterial volatile, 2,4-di-tert-butylphenol (45-47). Similarly, in the present study, root treatment with the strains GC-B19 and MM-B22 and BABA (positive chemical control) inhibited the infection process (conidial germination and appressorium formation) of $C$. orbiculare, and reduced disease severity in cucumber leaves. In contrast, non-ISR-eliciting strain, Pseudomonas aeruginosa PK-B09, failed to inhibit fungal infection process and disease expression. These results imply that the presence of strains GC-B19 and MMB22 in the rhizosphere elicited ISR to suppress disease development in leaves. This ISR-related disease suppression was strongly supported by the rapid induction of cell death, accompanied by an oxidative burst, such as $\mathrm{H}_{2} \mathrm{O}_{2}$ generation, and accumulation of defense-related enzymes triggered by treatment with the bacterial strains being tested, similar to the results produced by treatment with the chemical inducer BABA.

In general, ISR in plants elicited by beneficial microbes, chemicals, or composts can effectively respond to pathogen infection by inducing faster and stronger defense-related physiological and biochemical changes $(8,42,44,54)$. In our previous study, we observed that root treatments with compost water extracts (abiotic factors) rapidly triggered ISR, but only in cucumber leaves infected with $C$. orbiculare (44). Similarly, in this study, root treatments with the two bacterial strains (biotic factors) being investigated rapidly triggered biochemical and physiological responses in cucumber leaves after inoculation with $C$. orbiculare. However, in the absence of the pathogen, these strains did not activate defense responses. This plant state can be regarded as the primed state for defense, because plant resistance is activated

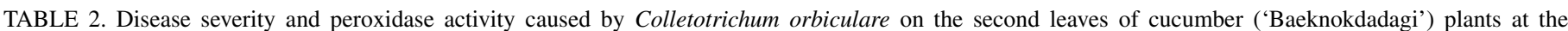

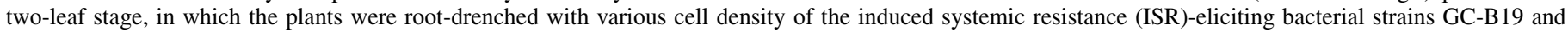
MM-B22 5 days before inoculation ${ }^{\mathrm{w}}$

\begin{tabular}{|c|c|c|c|c|c|c|}
\hline \multirow[b]{2}{*}{ Treatment } & \multirow[b]{2}{*}{ Bacterial density } & \multirow[b]{2}{*}{ Disease severity $(\%)^{\mathrm{x}}$} & \multicolumn{2}{|c|}{ Peroxidase activity $y$} & \multicolumn{2}{|c|}{ IC vs. $\mathrm{UC}^{\mathrm{z}}$} \\
\hline & & & Inoculated & Uninoculated & $F$ & $P>F$ \\
\hline $\mathrm{MgSO}_{4}$ & & $3.4 \pm 0.2$ & $6.0 \pm 0.7$ & $3.4 \pm 0.5$ & 8.59 & 0.0064 \\
\hline BABA* & & $0.4 \pm 0.0$ & $18.7 \pm 2.3$ & $2.8 \pm 0.5$ & 47.28 & $<0.0001$ \\
\hline \multirow[t]{5}{*}{ GC-B19* } & $10^{2}$ & $3.1 \pm 0.2 \mathrm{a}$ & $4.6 \pm 1.2 \mathrm{c}$ & $2.2 \pm 0.1 \mathrm{~b}$ & 3.18 & 0.0977 \\
\hline & $10^{4}$ & $2.9 \pm 0.1 \mathrm{a}$ & $6.7 \pm 4.3 \mathrm{bc}$ & $2.3 \pm 0.2 b$ & 1.07 & 0.3209 \\
\hline & $10^{6}$ & $1.6 \pm 0.1 \mathrm{~b}$ & $14.0 \pm 1.1 \mathrm{ab}$ & $3.9 \pm 0.8 \mathrm{a}$ & 53.68 & $<0.0001$ \\
\hline & $10^{8}$ & $1.7 \pm 0.1 \mathrm{~b}$ & $14.5 \pm 1.6 \mathrm{a}$ & $3.3 \pm 0.6 \mathrm{ab}$ & 53.13 & $<0.0001$ \\
\hline & $10^{10}$ & $1.6 \pm 0.1 \mathrm{~b}$ & $16.5 \pm 3.6 \mathrm{a}$ & $2.6 \pm 0.6 \mathrm{ab}$ & 16.78 & 0.0013 \\
\hline \multirow[t]{5}{*}{ MM-B22* } & $10^{2}$ & $3.2 \pm 0.2 \mathrm{a}$ & $4.7 \pm 1.4 \mathrm{~b}$ & $2.1 \pm 0.2 \mathrm{~b}$ & 3.71 & 0.0762 \\
\hline & $10^{4}$ & $3.0 \pm 0.2 \mathrm{a}$ & $2.5 \pm 0.6 b$ & $2.4 \pm 0.2 b$ & 0.07 & 0.7934 \\
\hline & $10^{6}$ & $1.7 \pm 0.1 \mathrm{~b}$ & $16.5 \pm 2.5 \mathrm{a}$ & $3.4 \pm 0.9 \mathrm{ab}$ & 23.53 & 0.0003 \\
\hline & $10^{8}$ & $1.9 \pm 0.1 \mathrm{~b}$ & $14.1 \pm 2.3 \mathrm{a}$ & $3.8 \pm 0.7 \mathrm{ab}$ & 20.39 & 0.0006 \\
\hline & $10^{10}$ & $1.9 \pm 0.2 b$ & $15.2 \pm 1.2 \mathrm{a}$ & $4.5 \pm 1.0 \mathrm{a}$ & 48.73 & $<0.0001$ \\
\hline \multirow[t]{5}{*}{ PK-B09 } & $10^{2}$ & $3.2 \pm 0.1 \mathrm{a}$ & $1.6 \pm 0.4 \mathrm{c}$ & $2.5 \pm 0.5 b$ & 2.13 & 0.1702 \\
\hline & $10^{4}$ & $3.1 \pm 0.1 \mathrm{a}$ & $2.2 \pm 0.9 b c$ & $3.1 \pm 0.5 b$ & 0.65 & 0.4349 \\
\hline & $10^{6}$ & $3.8 \pm 0.3 \mathrm{a}$ & $3.8 \pm 0.9 b c$ & $5.1 \pm 0.7 \mathrm{ab}$ & 1.30 & 0.2741 \\
\hline & $10^{8}$ & $3.4 \pm 0.3 \mathrm{a}$ & $4.5 \pm 0.6 b$ & $4.1 \pm 0.7 \mathrm{a}$ & 0.19 & 0.6679 \\
\hline & $10^{10}$ & $3.4 \pm 0.3 \mathrm{a}$ & $9.2 \pm 1.7 \mathrm{a}$ & $5.2 \pm 0.6 \mathrm{a}$ & 5.14 & 0.0398 \\
\hline
\end{tabular}

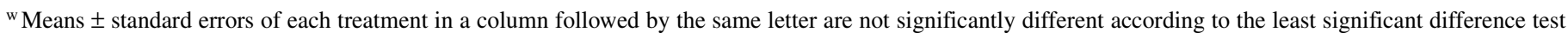
at $P<0.05$. An asterisk indicates a significant difference between the treatment and the $\mathrm{MgSO}_{4}$ solution (untreated control) at $P<0.05$ for disease severity and peroxidase activity. Experiments were conducted twice with three and six replicates each for peroxidase activity and disease severity, respectively.

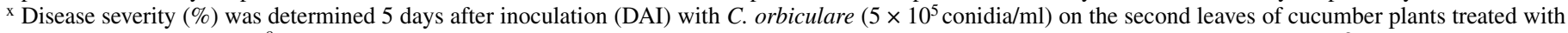
bacterial suspensions $\left(10^{8} \mathrm{cells} / \mathrm{ml}\right)$ of the ISR-eliciting strains and Pseudomonas aeruginosa PK-B09 (negative bacterial control), DL- $\beta$-amino- $n$-butyric acid (BABA; $100 \mu \mathrm{g} / \mathrm{ml}$ ) (positive chemical control), and $10 \mathrm{mM} \mathrm{MgSO}_{4}$ solution (untreated control). Uninoculated plants did not exhibit any disease symptoms.

y Peroxidase activity was assessed 3 DAI and expressed as the change in absorbance at $470 \mathrm{~nm} / \mathrm{min} / \mathrm{mg}$ of $\mathrm{protein}$.

${ }^{\mathrm{z}} F$ and $P$ values from contrast analysis of peroxidase activity between inoculated (IC) and uninoculated (UC) plants are presented. 
by pathogen infection. The priming response can protect plants against pathogen infection and also minimize the energy cost of defense (55). For example, when the costs and benefits of chemical-induced priming and direct defense in Arabidopsis were compared in the absence and presence of pathogens such as Pseudomonas syringae pv. tomato and Hyaloperonospora parasitica, the priming-mediated benefits (i.e., plant protection from pathogen infection) exceeded the fitness costs (i.e., energy used for defense) under pathogen attack (55). Heil and Baldwin (17) classified these costs into allocation costs, constitutive costs, autotoxicity costs, and ecological or environmental costs that could arise either internally or externally with respect to the ISRelicited plants. In this study, we did not examine these costs but, based on the present results, we suggest that strains GC-B19 and MM-B22 induce priming-mediated ISR at low fitness costs in the absence of the pathogen.

Defense-related enzymes, including peroxidase, are known to be involved in induced resistance in various plants $(6,15,34,49)$.
Irving and Kuć (19) reported that peroxidase and chitinase were induced locally and systemically in cucumber against $C$. orbiculare by treatment with $\mathrm{K}_{2} \mathrm{HPO}_{4}$. Subsequently, Chen et al. (5) observed that peroxidase and polyphenol oxidase were enhanced in cucumber roots treated with resistance-inducing PGPR, after inoculation with Pythium aphanidermatum. Therefore, we used peroxidase activity as an index of the enzymes being tested ( $\beta$-1,3-glucanase, chitinase, and peroxidase) to determine whether ISR expression might be bacterial density-dependent in the cucumber rhizosphere. Root treatments with strains GC-B19 and MM-B22 at high density $\left(10^{6}\right.$ to $10^{10}$ cells/g of potting mix) produced higher peroxidase activity and lower disease severity in the inoculated leaves than the control treatment such as strain PKB09 or $\mathrm{MgSO}_{4}$ solution; however, low-density $\left(10^{2}\right.$ to $10^{4}$ cells/g of potting mix) bacterial treatment failed to enhance enzyme activity and to reduce disease severity. This cell densitydependent ISR expression can also be explained by the results of contrast analysis in peroxidase activity between inoculated and
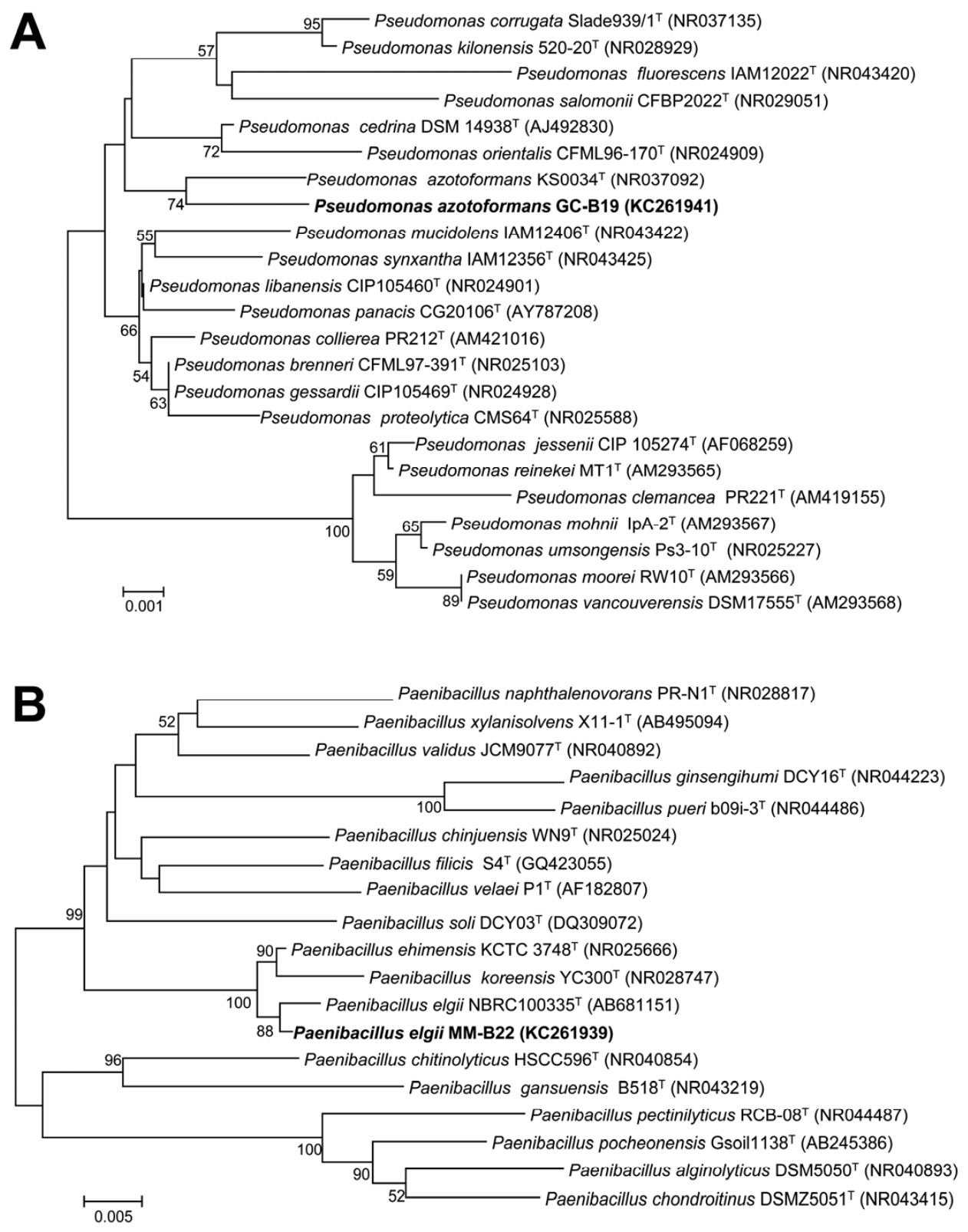

Fig. 4. Phylogenetic neighbor-joining trees of the induced systemic resistance-eliciting bacterial strains A, GC-B19 and B, MM-B22 with other related species in the genera Pseudomonas and Paenibacillus, respectively. Bootstrap values (>50\%) of 1,000 replicates are shown at the branch points. The scale bar represents (A) one or (B) five nucleotide substitutions per 1,000 nucleotides of the 16S rRNA sequence. Strains GC-B19 and MM-B22 tested in this study are shown in bold type. GenBank accession numbers are presented in parentheses. T indicates type strain of the species. 
uninoculated leaves, in which significant differences were detected in the high cell density, not in the low cell density. Thus, these results suggest that ISR expression against $C$. orbiculare in cucumber leaves is dependent on the bacterial cell density in the rhizosphere; resistance expression is derived from sustained bacterial populations ranging from $10^{4}$ to $10^{6}$ cells/g of potting mix over a period time after the bacteria $\left(10^{6}\right.$ to $10^{10}$ cells $/ g$ of potting mix) are introduced into the rhizosphere.

In this study, we used two ISR-eliciting bacterial strains, GC-B19 and MM-B22, identified as Pseudomonas azotoformans and Paenibacillus elgii, respectively; these strains, having biocontrol ability against cucumber anthracnose, might be additions for biological characteristics in their individual species. The genus Pseudomonas contains many species, such as Pseudomonas fluorescence, Pseudomonas putida, Pseudomonas chlororaphis, and Pseudomonas aeruginosa with biological activity associated with plant-growth promotion and/or ISR against plant diseases $(2,13,39)$. Previously, Pseudomonas azotoformans strains collected from rice fields were found to be free-living $\mathrm{N}$-fixing bacteria that did not promote plant growth (40). Another study showed that a strain of Pseudomonas azotoformans could degrade an herbicide (cyhalofop-butyl) used to control grasses in ricegrowing fields (36). In contrast, genus Paenibacillus is known to produce broadly antimicrobial compounds, including peptide antibiotics $(33,58)$. In particular, several strains of Paenibacillus elgii were reported to have antimicrobial or chitinolytic activity, as well as phosphate solubilization or plant growth promotion activity $(7,23)$.

Taken together, our results showed that Pseudomonas azotoformans GC-B19 and Paenibacillus elgii MM-B22 effectively induced ISR against $C$. orbiculare in cucumber, resulting in inhibition of fungal infection process (conidial germination and appressorium formation) and reduction of disease severity. The strains triggered rapid HR-like cell death with $\mathrm{H}_{2} \mathrm{O}_{2}$ accumulation and accumulation of defense-related enzymes in leaves primed against the pathogen. In addition, ISR expression was dependent on the bacterial cell density in the rhizosphere. Therefore, we suggest that priming-mediated ISR against $C$. orbiculare in cucumber can be induced in a bacterial density-dependent manner by Pseudomonas azotoformans GC-B19 and Paenibacillus elgii MM-B22.

\section{ACKNOWLEDGMENTS}

This study was supported by Korea University, the Agricultural R\&D Promotion Center, and the R\&D Program of MKE/KEIT (10035386, biochemical crop protecting agents for LOHAS). We thank C.-M. Ryu and J. K. Hong for critical reading of this manuscript.

\section{LITERATURE CITED}

1. Abeles, F. B., Bosshart, R. P., Forrence, L. E., and Habig, W. H. 1970. Preparation and purification of glucanase and chitinase from bean leaves. Plant Physiol. 47:129-134.

2. Bakker, P. A. H. M., Pieterse, C. M. J., and van Loon, L. C. 2007. Induced systemic resistance by fluorescent Pseudomonas spp. Phytopathology 97: 239-243.

3. Benhamou, N., Gagné, S., Le Quéré, D., and Dehbi, L. 2000. Bacterialmediated induced resistance in cucumber beneficial effect of the endophytic bacterium Serratia plymuthica on the protection against infection by Pythium ultimum. Phytopathology 90:45-56.

4. Bradford, M. M. 1976. A rapid and sensitive method for the quantification of microgram quantities of protein utilizing the principle of protein-dye binding. Anal. Biochem. 72:248-254.

5. Chen, C., Bélanger, R., Benhamou, N., and Paulitz, T. C. 2000. Defense enzymes induced in cucumber roots by treatment with plant growthpromoting rhizobacteria (PGPR) and Pythium aphanidermatum. Physiol. Mol. Plant Pathol. 56:13-23.

6. Dalisay, R. F., and Kuć, J. A. 1995. Persistence of induced resistance and enhanced peroxidase and chitinase activities in cucumber plants. Physiol. Mol. Plant Pathol. 47:315-327.
7. Das, S. N., Dutta, S., Kondreddy, A., Chilukoti, N., Pullabhotla, S. V. S. R. N., Vadlamudi, S., and Podile, A. R. 2010. Plant growth-promoting chitinolytic Paenibacillus elgii responds positively to tobacco root exudates. J. Plant Growth Regul. 29:409-418.

8. Dietrich, R., Ploss, K., and Heil, M. 2005. Growth responses and fitness costs after induction of pathogen resistance depend on environmental conditions. Plant Cell. Environ. 28:211-222.

9. Doke, N., and Ohashi, Y. 1988. Involvement of an $\mathrm{O}_{2}^{-}$generating system in the induction of necrotic lesions on tobacco leaves infected with tobacco mosaic virus. Physiol. Mol. Plant Pathol. 32:163-175.

10. Felsenstein, J. 1985. Confidence limits on phylogenies: an approach using the bootstrap. Evolution 39:783-791.

11. Gay, C., Collins, J., and Gebicki, J. M. 1999. Determination of iron in solutions with the ferric-xylenol orange complex. Anal. Biochem. 273: 143-148.

12. Goellner, K., and Conrath, U. 2008. Priming: it's all the world to induced disease resistance. Eur. J. Plant Pathol. 121:233-242.

13. Gül, A., Ŏzaktan, H., Kıdoğlu, F., and Tüzel, Y. 2013. Rhizobacteria promoted yield of cucumber plants grown in perlite under Fusarium wilt stress. Sci. Hortic.-Amsterdam 153:22-25.

14. Hammerschmidt, R. 1999. Induced disease resistance: how do induced plants stop pathogen? Physiol. Mol. Plant Pathol. 55:77-84.

15. Hammerschmidt, R., Nuckles, E. M., and Kuć, J. 1982. Association of enhanced peroxidase activity with induced systemic resistance of cucumber to Colletotrichum lagenarium. Physiol. Plant Pathol. 20:73-82.

16. Heil, M. 2002. Ecological costs of induced resistance. Curr. Opin. Plant Biol. 5:345-350.

17. Heil, M., and Baldwin, I. T. 2002. Fitness costs of induced resistance: emerging experimental support for a slippery concept. Trends Plant Sci. 7:61-66.

18. Heil, M., Hilpert, A., Kaiser, W., and Linsenmair, K. E. 2000. Reduced growth and seed set following chemical induction of pathogen defence: Dose systemic acquired resistance (SAR) incur allocation costs? J. Ecol. 88:645-654.

19. Irving, H. R., and Kuć, J. A. 1990. Local and systemic induction of peroxidase, chitinase and resistance in cucumber plants by $\mathrm{KH}_{2} \mathrm{PO}_{4}$. Physiol. Mol. Plant Pathol. 37:355-366.

20. Jeun, Y. C., Siegrist, J., and Buchenauer, H. 2000. Biochemical and cytological studies on mechanisms of systemically induced resistance in tomato plants. J. Phytopathol. 140:129-140.

21. Jurriaan, T., Jakab, G., Toquin, V., Flors, V., Iavicoli, A., Maeder, M. N., Metraux, J.-P., and Mauch-Mani, B. 2005. Dissecting the $\beta$-amino-butyric acid-induced priming phenomenon in Arabidopsis. Plant Cell 17:987-999.

22. Kauffmann, S., Legrand, M., Geoffroy, P., and Fritig, B. 1987. Biological function of 'pathogenesis-related' proteins: four PR proteins of tobacco have 1,3- $\beta$-glucanase activity. EMBO J. 6:3209-3212.

23. Kim, D.-S., Bae, C.-Y., Jeon, J.-J., Chun, S.-J., Oh, H. W., Hong, S. G., Baek, K.-S., Moon, E. Y., and Bae, K. S. 2004. Paenibacillus elgii sp. nov., with broad antimicrobial activity. Int. J. Syst. Evol. Microbiol. 54:2031-2035.

24. Kim, H.-S., Sang, M. K., Jung, H. W., Jeun, Y.-C., Myung, I. S., and Kim, K. D. 2012. Identification and characterization of Chryseobacterium wanjuense strain KJ9C8 as a biocontrol agent against Phytophthora blight of pepper. Crop Prot. 32:129-137.

25. Kim, P. I., and Chung, K.-C. 2004. Production of an antifungal protein for control of Colletotrichum lagenarium by Bacillus amyloliquefaciens MET0908. FEMS Microbiol. Lett. 234:177-183.

26. Kloepper, J. W., Tuzun, S., and Kuć, J. 1992. Proposed definitions related to induced disease resistance. Biocontrol Sci. Technol. 2:347-349.

27. Kuć, J. 1982. Induced immunity to plant disease. Bioscience 32:854-860.

28. Kumar, S., Tamura, K., and Nei, M. 2004. MEGA3: Integrated software for molecular evolutionary genetics analysis and sequence alignment. Brief Bioinform. 5:150-163.

29. Kunz, W., Schurter, R., and Maetzke, T. 1997. The chemistry of benzothiadiazole plant activators. Pest. Sci. 50:275-282.

30. Kwack, M. S., Kim, E. N., Lee, H., Kim, J.-W., Chun, S.-C., and Kim, K. D. 2005. Digital image analysis to measure lesion area of cucumber anthracnose by Colletotrichum orbiculare. J. Gen. Plant Pathol. 71:418421.

31. Kwack, M. S., Park, S. G., Jeun, Y. C., and Kim, K. D. 2002. Selection and efficacy of soil bacteria inducing systemic resistance against Colletotrichum orbiculare on cucumber. Mycobiology 30:31-36.

32. Levene, H. 1960. Contributions to Probability and Statistics: Essays in Honor of Harold Hotelling. Stanford University Press, Stanford, CA.

33. Li, J., Beatty, P. K., Shah, S., and Jensen, S. E. 2007. Use of PCR-targeted mutagenesis to disrupt production of fusaricidin-type antifungal antibiotics in Paenibacillus polymyxa. Appl. Environ. Microbiol. 73:3480-3489.

34. Miyazawa, J., Kawabata, T., and Ogasawara, N. 1998. Induction of an acidic isozyme of peroxidase and acquired resistance to wilt disease in response to treatment of tomato roots with 2-furoic acid, 4-hydroxy- 
benzoic hydrazide or salicylic hydrazide. Physiol. Mol. Plant Pathol. 52:115-126.

35. Nandarkumar, R., Babu, S., Viswanathan, R., Raguchander, T., and Samiyappan, R. 2001. Induction of systemic resistance in rice against sheath blight disease by Pseudomonas fluorescens. Soil Biol. Biochem. 33:603-612.

36. Nei, Z.-J., Hang, B.-J., Cai, S., Xie, X.-T., He, J., and Li, S.-P. 2011. Degradation of cyhalofop-butyl (CyB) by Pseudomonas azotoformans strain QDZ-1 and cloning of a novel gene encoding CyB-hydrolyzing esterase. J. Agric. Food Chem. 59:6040-6046.

37. Niranjan Raj, S., Lavanya, S. N., Amruthesh, K. N., Nirnjana, S. R., Reddy, M. S., and Shetty, H. S. 2012. Histo-chemical changes induced by PGPR during induction of resistance in pearl millet against downy mildew disease. Biol. Control 60:90-102.

38. Oostendorp, M., Kunz, W., Dietrich, B., and Staub, T. 2001. Induced systemic resistance in plants by chemicals. Eur. J. Plant Pathol. 107:1928.

39. Pandey, P. K., Yadav, S. K., Singh, A., Sarma, B. K., Mishra, A., and Singh, H. B. 2012. Cross-species alleviation of biotic and abiotic stresses by the endophyte Pseudomonas aeruginosa PW09. J. Phytopathol. 160:532-539.

40. Piao, Z., Cui, Z., Yin, B., Hu, J., Zhou, C., Xie, G., Su, B., and Yin, S. 2005. Changes in acetylene reduction activities and effects of inoculated rhizosphere nitrogen-fixing bacteria on rice. Biol. Fertil. Soils 41:371378.

41. Ruess, W., Mueller, K., Knauf-Veiter, G., Kunz, W., and Staub, T. 1996. Plant activator CGA 245704: An innovative approach for disease control in cereals and tobacco. Pages 53-60 in: Proceedings of the Brighton Crop Protect Conference-Pests and Diseases. British Crop Protection, Alton, Hampshire, UK.

42. Ryu, C.-M., Farag, M. A., Hu, C-H., Reddy, M. S., Wei, H. X., Pare, P. W., and Kloepper, J. W. 2003. Bacterial volatiles promote growth in Arabidopsis. Proc. Natl. Acad. Sci. U.S.A. 100:4927-4932.

43. Saitou, N., and Nei, M. 1987. The neighbor-joining method: a new method for reconstructing phylogenetic trees. Mol. Biol. Evol. 4:406-425.

44. Sang, M. K., and Kim, K. D. 2011. Biological activity and primed systemic resistance by compost water extracts against anthracnoses of pepper and cucumber. Phytopathology 101:732-740.

45. Sang, M. K., and Kim, K. D. 2012. The volatile-producing Flavobacterium johnsoniae strain GSE09 shows biocontrol activity against Phytophthora capsici in pepper. J. Appl. Microbiol. 113:383-398

46. Sang, M. K., Kim, J. D., Kim, B. S., and Kim, K. D. 2011. Root treatment with rhizobacteria antagonistic to Phytophthora blight affects anthracnose occurrence, ripening, and yield of pepper fruit in the plastic house and field. Phytopathology 101:666-678.

47. Sang, M. K., Shrestha, A., Kim, D.-Y., Park, K., Pak, C. H., and Kim, K. D. 2013. Biocontrol of Phytophthora blight and anthracnose in pepper by sequentially selected antagonistic rhizobacteria against Phytophthora capsici. Plant Pathol. J. 29:154-167.

48. Schraudner, M., Moeder, W., Wiese, C., Van Camp, W., Inzé, D., Langebartels, C., and Sandermann, H., Jr. 1998. Ozone-induced oxidative burst in the ozone biomonitor plant, tobacco Bel W3. Plant J. 16:235-245.

49. Shoresh, M., Yedidia, I., and Chet, I. 2005. Involvement of jasmonic acid/ethylene signaling pathway in the systemic resistance induced in cucumber by Trichoderma asperellum T203. Phytopathology 95:76-84.

50. Sticher, L., Mauch-Mani, B., and Métraux, J. P. 1997. Systemic acquired resistance. Annu. Rev. Phytopathol. 35:235-270.

51. Thompson, D. C., and Jenkins, S. F. 1985. Influence of cultivar resistance, initial disease, environment, and fungicide concentration and timing on anthracnose development and yield loss in pickling cucumbers. Phytopathology 75:1422-1427.

52. Thompson, J. D., Gibson, T. J., Plewniak, F., Jeanmougin, F., and Higgins, D. G. 1997. The CLUSTAL_X windows interface: flexible strategies for multiple sequence alignment aided by quality analysis tools. Nucleic Acids Res. 25:4876-4888.

53. Thordal-Christensen, H., Zhang, Z., Wei, Y., and Collinge, D. B. 1997. Subcellular localization of $\mathrm{H}_{2} \mathrm{O}_{2}$ in plants. $\mathrm{H}_{2} \mathrm{O}_{2}$ accumulation in papillae and hypersensitive response during the barley-powdery mildew interaction. Plant J. 11:1187-1194.

54. Tjamos, S. E., Flemetakis, E., Paplomatas, E. J., and Katinakis, P. 2005. Induction of resistance to Verticillium dahliae in Arabidopsis thaliana by the biocontrol agent K-165 and pathogenesis-related proteins gene expression. Mol. Plant-Microbe Interact. 18:555-561.

55. Van Hulten, M., Pelser, M., Van Loon, L. C., Pieterse, C. M. J., and Ton, J. 2006. Costs and benefits of priming for defense in Arabidopsis. Proc. Natl. Acad. Sci. U.S.A. 103:5602-5607.

56. Wei, G., Kloepper, J. W., and Tuzun, S. 1991. Induction of systemic resistance of cucumber to Colletotrichum orbiculare by selected strains of plant growth-promoting rhizobacteria. Phytopathology 81:1508-1512.

57. Weisburg, W. G., Barns, S. M., Pelletier, D. A., and Lane, D. J. 1991. 16S ribosomal DNA amplification for phylogenetic study. J. Bacteriol. 173:697-703.

58. Wu, X.-C., Shen, X.-B., Ding, R., Qian, C.-D., Fang, H.-H., and Li, O. 2010. Isolation and partial characterization of antibiotics produced by Paenibacillus elgii B69. FEMS Microbiol. Lett. 310:32-38.

59. Yi, H.-S., Heil, M., Adame-Álvarez, R. M., Ballhorn, D. J., and Ryu, C.M. 2009. Airborne induction and priming of plant defenses against a bacterial pathogen. Plant Physiol. 151:2152-2161. 